\title{
Difficulties Experienced during Implementation of an Adapted Quality Management System in Incubated Companies
}

\author{
Rosley Anholon ${ }^{1}$, Eugênio José Zoqui ${ }^{1}$, Jefferson de Souza Pinto ${ }^{1} \&$ Olívio Novaski ${ }^{1}$ \\ ${ }^{1}$ Department of Manufacturing Engineering and Materials, School of Mechanical Engineering, University of \\ Campinas, Brazil \\ Correspondence: Rosley Anholon, School of Mechanical Engineering, University of Campinas, São Paulo, Brazil. \\ Tel: 55-19-3521-3312. E-mail: rosley@fem.unicamp.br
}

Received: December 12, 2014

Accepted: January 6, 2015

Online Published: January12, 2015

doi:10.5430/bmr.v4n1p34

URL: http://dx.doi.org/10.5430/bmr.v4n1p34

\begin{abstract}
The purpose of this paper is presents a study to find out the main difficulties experienced by nine micro and small enterprises throughout the implementation of a quality management system adapted to the reality of companies incubated. According to the objective presented, the article used the case study technique applied in nine incubated company, emphasizing the difficulties observed during the implementation of quality management system adapted to their realities. After the implementation, those companies showed significant progress in their management models. However we observed some gaps to conquer better results, such as difficulties in establishing long-term goals; non-financial targets; the idea that employees can't help in the improvement company, among other difficulties reported in this paper. In the literature there are a lot of papers about quality management in micro and small enterprises, but this work stands out for analyze a specific kind of company, micro and small companies incubated. This is the main difference and value.
\end{abstract}

Keywords: Quality management system, Micro and small enterprises, Incubated companies

Paper type: Case Study.

\section{Introduction}

The importance of micro and small enterprises to the country has already been known, according to the Brazilian Service of Support for Micro and Small Enterprises (SEBRAE-SP, 2013). According to the institution, those organizations are responsible for hiring of $69 \%$ of the economically active population in the urban environment and contribute with $24 \%$ of net wealth generated by the nation. Such data, when associated with entrepreneurial activities, demonstrate a great prospect for the country. According to a survey conducted annually by the Babson College, U.S.A. and the London Business School, England, Brazil is characterized as one of the most entrepreneurial countries in the world (GEM 2013).

Despite the great correlation between the importance of micro and small enterprises to the country and high rates of entrepreneurism, Brazil still has a high mortality rate for enterprises with up to four years of existence when compared to developed countries, according to SEBRAE (2013). The explanation for this occurrence lies in the fact that most Brazilian entrepreneurs do not have managerial knowledge or are unprepared to face a highly competitive market. A Babson College and London Business School survey also showed that in Brazil most companies is created by necessity and not by opportunity. People undertake when they lose a job or when they need to increase their income, not having, thus, enough preparation to fulfill this challenge (GEM 2013).

To reduce this high mortality rate, institutions as SEBRAE, federations and confederations of industries of each state and federal government, through the Ministry of Science and Technology, have developed a series of programs aimed at better structuring of newly created enterprises, for example, the installation of core business development (or simply enterprise incubators) in various cities of the country. According to MST (2014, p. 6), an incubator can be understood as a "mechanism that encourages the creation and development of micro and small industrial or service enterprises, technology-based or light manufacturing through entrepreneurial additional training in its technical and managerial aspects." Focusing on the managerial aspects, this additional training is offered through consulting in strategic planning areas, marketing, finance, and quality, among others. These activities logically do not guarantee the survival of a newly created business, but practically reduce to half the mortality rates for the participating 
businesses, acoording to Al-Mubaraki, and Busler (2010) and Wonglimpiyarat (2014).

In this context, this article aims to present the main difficulties observed during the implementation of an adopted quality management system in micro and small business, more precisely nine located in the Center for Entrepreneurial Development Jundiaí (the problem issue associated to this objective is: "which are the main difficulties observed during the implementation of an adopted quality management system in micro and small business?). During a year, we were consultants in the incubated companies and the experiences of the implementation are described herein.

\section{Literature Review}

\subsection{Classification, Regulation and Importance of the MSES}

Despite having many features similar to larger business, micro and small enterprises (MSEs) have peculiarities that can lead them to failure or success, depending on how they are managed. To better understand these companies reality, it is interesting to present the classification criteria commonly used in Brazil, the country in which the research was conducted.

The most widespread and more reported criteria in the literature corresponds to what is used by the Brazilian Service of Support for Micro and Small Enterprises (SEBRAE, 2014), which classifies the companies size by number of employees. Table 1 shows that criterion.

Table 1. Classification of enterprise by number of employees (SEBRAE, 2014).

\begin{tabular}{ccc}
\hline Classification & Industrial Sector & Services and Trade \\
\hline Micro business & $0-19$ employees & $0-9$ employees \\
\hline Small Business & $20-99$ employees & $00-49$ employees \\
\hline Medium-Sized Business & $100-499$ employees & $50-99$ employees \\
\hline Large Business & above 499 employees & above 499 employees
\end{tabular}

Another classification criterion corresponds to that used by the Brazilian government for revenue collection. This classification is established by the statute for micro and small enterprises Decree No. 5028, considering micro businesses those that have annual gross income equal to or less than $\mathrm{R} \$ 433,755.14$ and small businesses those with annual gross income not exceeding $\mathrm{R} \$ 2,133.222,00$.

Eikebrokk \& Olsen (2007), however, criticize classification criteria related to the number of employees and annual revenues. For the first criterion, in particular, these authors present examples of European enterprises from the knowledge and information sector that turnover millions in business and have global significance with only a small team. Longenecker et al., (2013) also consider difficult to define a single criterion for classification of micro and small enterprises. For these authors, a variety of criteria and references obeys conditions as purpose of the user or interested organ, region and analysed country, stage of economic development and structure of the enterprise.

The importance of micro and small enterprises for Brazil's development is constantly highlighted in the media and in academia. According to SEBRAE (2013), these companies constitute $99 \%$ of legally registered enterprises, employing $67 \%$ of the economically active population, i.e., active population in the labor market and working age and have a stake in the Brazilian Gross Domestic Product of around 23\%.

\subsection{State of the art: related work presented in this article}

This section aims to review the literature by presenting studies that are directly correlated to the subject studied in this article. This literature review is in chronological order, pointing out in chronological order the main concepts and contributions of each researched study.

Hakserver (1996) broadly presents possibilities, potentials and problems that the implementation of Total Quality Management (TQM) can provide to American small enterprises. Of this study, the authors of this article have relied mainly on information correlated to motivation, empowerment, team building and recognition of contributors as key element for successes of small business.

McAdam (2000) made a critical analysis of TQM implementation in the context of small businesses based on 20 case studies. We found that TQM implementation can be compromised by bureaucracy and by the existence of 
purely mechanistic models, it is necessary to link innovation and flexibility aspects. Moreover, it also stressed that the small enterprises environment is very dynamic and they need constant updating.

Nwankwo (2000) talked about myths and realities observed in the implementation of quality standards in two small businesses in the UK and highlighted that despite rapid dynamism that implementation can provide, many companies still overlook the strategic thinking and develop the skills needed to incorporate a total quality orientation. This study was extremely important for this article, for strengthen the need of phases related to definition and refinement of goals and strategies.

Spencer \& Lomba (2001) carried out an extensive study in manufacturing enterprises of American small enterprises, in order to analyze TQM contribution and their tools for administrative management. Concluding, they have established that quality control circles, tools of statistical control, synergy, among other TQM concepts were essential to the success of the analyzed enterprises, which supports the authors' view regarding this article, that quality management is plausible to micro and small enterprises reality.

Williams et al., (2001) pointed out as main conclusion of their study the need for ISO 9000 series is considered in a broader manner, by integrating TQM principles. These recommendations were considered during the quality management system quality management adapted at the time it was sought a comprehensive infrastructure which embraced diverse needs of micro and small businesses.

Biazzo \& Bernadelli (2003) presented a study on the risks and opportunities of using the Quality Management System based on ISO 9000 series and, despite they did not establish types or size of the companies in their conclusions, they made it clear that each enterprise must develop a management system shaped to its reality.

Youssef \& Aldowaisan (2006) presented a different way for the implementation of ISO 9001 in small enterprises, according to which the traditional model of identification of processes, development of Quality Management System, implementation and its maintenance can be replaced by a model in which it set a Quality Management System of simplified processes, going for a basic system and getting to a multithreaded system, and then implement, formalize and establish its maintenance. This study was interesting because it made even more clear to us that micro and small enterprises require maturation phase of what is being implemented, generating learning and gain in terms of management.

Sousa-Poza et al., (2008) presented a conceptual study that established guidelines for a Quality Management System implementation ISO 9001, facing the reality of small and medium enterprises. They established four initial phases to reach a minimum standard required and subsequently five more steps to move it to a desirable standard in quality management terms. These authors established interesting definitions for the reality they observed in the studied companies when they defined their stages of management as $100 \%$ alive and formal (there is standardized documentation and processes are functional), $100 \%$ alive and informal (there is no standardized documentation, but processes are functional), $100 \%$ dead and formal (there is standardized documentation, but nothing functional), or $100 \%$ dead and informal (there is no standardized documentation and nothing works). This study guided us to the need to establish a management system oriented to micro and small enterprises that were $100 \%$ live and formal.

Munsterman et al., (2010) presented an interesting study at the time they sought to assess the standardization of processes impacts on enterprises performance, but specifically related to time, cost and quality and, therefore, they analyzed 156 companies through the hypothesis testing. The findings showed statistically significant impact on improving performance after standardized processes, which corroborates our article, on the effectiveness of management systems in companies.

Kumar et al., (2009) used the Total Quality Management tools to solve problems in a medium-sized Indiain industry that manufactured steel wire for concrete beams. Using techniques such as brainstorming, cause and effect diagram and Pareto analysis they had excellent results in reducing wire fragmentation, showing that simple management tools are extremely useful to small enterprises.

Koc (2011) investigated the relation between Total Quality Management elements, failures and performance in small and medium-sized businesses. The results of the study revealed that there is a significant relation between TQM practices, internal and external failures and company performance. Employee involvement, customer focus and quality system are found to be significant predictors for the relation previously described.

Ilkai and Aslan (2012) developed a very interesting research when analyzed 255 small and middle-sized enterprises, trying to verify through analysis of variance if there was a difference in terms of performance for certified and not certified companies ISO 9001. The results showed that for the analyzed group there were no statistically significant differences between the two groups, which called our attention to the fact that a Quality Management System needs 
to be part of the company culture and not be characterized only as formalization of documents.

\section{Method}

\subsection{Research Classification}

Based on the information previously reported, we proceed to the classification of the research presented in this article. From the point of view of the broad methods, it presents deductive characteristics, since the results presented here are obtained from the quality management system implementation adapted in nine companies of the Center for Entrepreneurial Development Jundiaí and there was not a representative sample for induction.

From the point of view of approaching the problem, this research presents a qualitative character, since the implementation of quality management system are described in detail, the administrative evolution of each company and the main difficulties observed during its implementation.

Regarding technical procedures, this research can be classified as literature review and case study, depending on development stage in which it is inserted. Initially, a review of the literature was done to generate necessary knowledge about micro and small companies and quality management system. In a second moment, a adapted quality managemnet system was implemented in nine companies of the Center for Entrepreneurial Development Jundiaí, and at that moment the research could be classified as case study research, since we described the characteristics of implementation process and the difficulties observed.

Focusing on the nature of the research, it can be classified as descriptive and applied once it aimed to present the main difficulties in a Quality Management System implementation adapted to micro and small enterprises. Finally, it should be noted that the data collection technique used was cases studies.

\subsection{Quality management system adapted to micro and small enterprises reality}

For this article, we used a system of quality management adapted to micro and small enterprises used in the Jundiaí Business Incubator and some concepts present in Anholon (2005). In general, this management system covers aspects related to quality management, systematic reviews, strategic planning concepts and simplified documentation based on ISO 9001 standard (ISO, 2008). It is structured into eight phases shown in Figure 1.

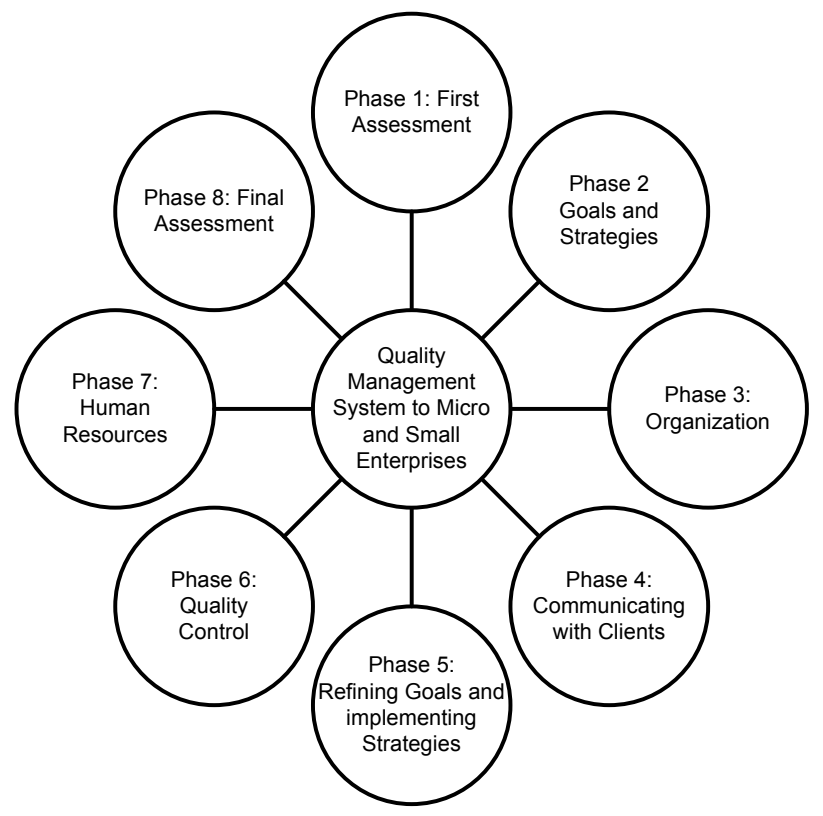

Figure 1. Phases of the Quality Management System adapted to micro and small enterprises.

The implementation begins with the completion of an assessment based on Paulista Award for Quality Management (IPEG, 2013) through which the situation of the incubated companies is evaluated. This evaluation is structured into eight criteria and each of them has five items, totaling 40 questions. The maximum score to be obtained is 250 points divided as follows among the criteria: 
1 - Leadership (20 points);

2 - Strategies, Goals and Plans (20 points);

3- Customers (20 points);

4- Community (10 points);

5 - Information and Knowledge (15 points);

6 - Contributors (15 points);

7 - Processes (40 points) and

8 - Results (110 points)

In the second phase are established goals, strategic plans and performance indicators, relied upon a few simple concepts from the Balanced Scorecard (KAPLAN \& NORTON, 1997) applicable to micro and small enterprises. The main idea is to motivate entrepreneurs to develop two simple goals for each of the four perspectives (financial, customers, internal processes and learning and growth of contributors), to analyze how each process may contribute to the achievement of these goals and define 1 or 2 performance indicators for each area. Such goals, strategic plans and indicators are only put into practice after the company's organization and the establishment of a communication channel with customers (stages 3 and 4), thus permitting greater reflection about the predetermined goals.

The third phase is dedicated to the company's organization and is through the implementation of 5S Program and some procedures related to maintenance, cleaning the work environment, document control and audits made by checklists. Sense of use, order, cleanliness, health and self-discipline are developed, always trying to motivate the company's contributors.

In the fourth phase, in turn, organizational activities of the client's portfolio are developed, establishment of a communication channel with them and conduction of a research to raise their levels of satisfaction. The problems of complaints or dissatisfaction at this stage and at the previous stage are solved by the Method of Analysis and Troubleshooting (Falconi, 1992).

The fifth phase begins with a discussion of the benefits achieved by the company until the moment. This reflection contributes to improve goals, strategic plans and the indicators that were developed in the second phase. The period between the second and the fifth phase is important for maturation of the metrics developed and, if businessmen deem it necessary, may establish corrections before final implementation.

The sixth phase focuses on the implementation of a system of quality control through which the company will identify whether its products or services meet the technical specifications and customers. This phase was also characterized by the implementation of work instructions and some procedures based on ISO 9001 standard (ISO, 2008).

In the seventh stage the development of a human resources policy begins, where some training are held to enhance the intellectual training of the contributors. We emphasize that this phase presents only an introduction to personnel management, since many companies are not yet prepared for such practices.

Finally, during the eighth stage, it takes place again the assessment based on Paulista Award for Quality Management (IPEG, 2013), and then, it can be seen the value aggregation provided by the quality management system adapted. Based on the total scores and for each criterion it can be seen what were the most problematic points for each company and thus act in a customized manner for each of them.

The phases described above are developed over a year, divided according to Table 2. In order to facilitate the implementation of these system manuals, examples of procedures and weekly consultations are available. At the end of one year, the cycle of eight phases is redone seeking to achieve continuous improvement. 
Table 2. Schedule used for the implementation of the adapted quality management system

\begin{tabular}{|c|c|c|c|c|c|c|c|c|c|c|c|c|c|}
\hline \multirow{2}{*}{$\mathrm{N}$} & \multirow{2}{*}{ Phases } & \multicolumn{12}{|c|}{ Months } \\
\hline & & 1 & 2 & 3 & 4 & 5 & 6 & 7 & 8 & 9 & 10 & 11 & 12 \\
\hline 1 & First Assessment & & & & & & & & & & & & \\
\hline 2 & Goals and Strategies & & & & & & & & & & & & \\
\hline 3 & Organization & & & & & & & & & & & & \\
\hline 4 & Communication with Clients & & & & & & & & & & & & \\
\hline 5 & Ref. Goals and Imp. Strategies & & & & & & & & & & & & \\
\hline 6 & Quality Control & & & & & & & & & & & & \\
\hline 7 & Human Resources & & & & & & & & & & & & \\
\hline 8 & Final Assessment & & & & & & & & & & & & \\
\hline
\end{tabular}

Source: (made by the authors of the article)

\section{Results}

\subsection{Description of participating business}

There is a brief description of the nine companies in which the quality management system adapted was implemented below, and some results. It can be observed that they differ greatly regarding the activity sector, number of contributors and behavior of their owners and managers. A common feature among them all is that they do not have more than four years of existence, when taken into consideration the legal status of the company.

a. Enterprise 1: it has only one proprietary with a moderate profile for changes and new management techniques, operating in the production and marketing of aromatic pillows. Its workforce consists of four employees and the results achieved with the quality management system implementation adapted were good, helping the entrepreneur to evolve her business management;

b. Enterprise 2: working in the sports apparel industry, this business is owned by two partners with a bold profile for changes. However, impairment to the activities of the quality program led them to abandon the implementation, thus injuring the results achieved. At the time of withdrawal, the workforce was composed of six contributors and the best results were related to communication with customers;

c. Enterprise 3: has only one owner with bold profile for changes and new management techniques, operating in the production and marketing of bags for musical instruments and diving. The rotation of workforce was large, ranging between five and six employees. It had some good results related to quality documentation, but no monitoring of non-financial performance indicators, as suggested by the adapted quality management system, led the company to a major crisis for four months. After this period the results reappeared and, in general, the company achieved satisfactory results;

d. Enterprise 4: with two partners, this company operates in the industrial automation sector manufacturing panels for control machines. The results were great, largely because of the bold profile of one of the partners, despite the high turnover of its workforce over the implementation;

e. Enterprise 5: this company operates in the machining services sector, consisting of two partners. Although one of them has a bold profile, the conservative profile of the other partner made impossible to obtain better results. The highlight was primarily for the company's organization and monitoring of performance indicators, as suggested by the second phase of the adapted quality management system. The workforce did not vary throughout the implementation, composed of five employees;

f. Enterprise 6: engaged in manufacturing and marketing of horseshoes for horses, owned by two brothers with moderate profile but strongly influenced by parental decisions with conservative profile. Its workforce has not changed over the adapted quality management system implementation, always with six employees. We observed great results related to customers contact in the administrative management and others great results in the productive sector results, although the company did not implement all the activities suggested; 
g. Enterprise 7: the company operates in the production and marketing of electrical components; it is owned by two businessmen, both with bold profile. Its workforce has increased from four to six employees due to the company growth. It obtained excellent results related to the organization and administration, the only problem was the constant tendency to generate more bureaucratic documents than the real needs of the company. This trend was due to previous owners' experience, when they worked in multinational companies, but this was corrected during the implementation.

h. Enterprise 8: this company produces and sells micro-sales terminals and stock control for businesses in general. Despite being owned by three partners, all activities and decisions are made by the daughter of one of them, who works as managing director. For this company the workforce also increased during the implementation, from seventeen to twenty employees due to the company' growth. It obtained excellent results, highlighting particularly the use of various records and documentation quality. It was the company with best performance in the adapted quality management system implementation.

i. Enterprise 9: being owned by two partners, this company operates in the design and marketing of large vibrating screens of the highest value added. At the beginning of the implementation the company had a high debt due to the lack of any machine sales and the turnover of the workforce was high. With two new orders, the situation was restored and the company achieved good results related to customers contact and organization.

It is interesting to also present the results of the initial and final evaluations of the adapted quality management system, through which it is possible to observe the companies' evolution. It is emphasized again that this assessment is based on the Paulista Award for Quality Management (PPQG, 2013) and it includes eight criteria with a maximum total score of 250 points. Table 3 shows that the largest changes were linked to companies 7, 8 and 9 . The Enterprise 2 did not actually complete the implementation activities and, therefore, has no score for the final evaluation.

Table 3. Evolution of the nine companies after the implementation of adapted quality management system. Source: (made by the authors of the article)

\begin{tabular}{cccccc}
\hline Business & $\begin{array}{c}\text { Initial } \\
\text { Assessment } \\
\text { Score }\end{array}$ & $\begin{array}{c}\text { \% Relative to the } \\
\text { maximum }\end{array}$ & $\begin{array}{c}\text { Score } \\
\text { Final } \\
\text { Assessment }\end{array}$ & $\begin{array}{c}\text { \% Relative to } \\
\text { the maximum }\end{array}$ & Evolution \\
\hline $\mathbf{1}$ & 34.00 & $13.60 \%$ & 75.50 & $30.20 \%$ & $16.60 \%$ \\
\hline $\mathbf{2}$ & 48.00 & $19.20 \%$ & $* * * *$ & $* * * *$ & $* * *$ \\
\hline $\mathbf{3}$ & 50.00 & $20.00 \%$ & 91.00 & $36.40 \%$ & $16.40 \%$ \\
\hline $\mathbf{4}$ & 44.00 & $17.60 \%$ & 103.00 & $41.20 \%$ & $23.60 \%$ \\
\hline $\mathbf{5}$ & 57.00 & $22.80 \%$ & 93.50 & $37.40 \%$ & $14.60 \%$ \\
\hline $\mathbf{6}$ & 47.50 & $19.00 \%$ & 87.50 & $35.00 \%$ & $16.00 \%$ \\
\hline $\mathbf{8}$ & 64.00 & $25.60 \%$ & 121.00 & $48.40 \%$ & $22.80 \%$ \\
\hline $\mathbf{9}$ & 59.75 & $23.90 \%$ & 128.00 & $51.20 \%$ & $27.30 \%$ \\
\hline
\end{tabular}

Item 4.2 of this article presents the main difficulties experienced during the quality management system implementation adapted to nine incubated companies of the Center for Entrepreneurial Development Jundiaí, previously reported. It is noteworthy that despite these difficulties, this system contributed positively to developments in administrative management of them all.

\subsection{Main difficulties observed in the implementation}

After a year of the implementation it was possible to observe that the adapted quality management system brought beneficial results to all companies that have completed the implementation, obviously at different scales. The efficiency of the quality management system in some companies could have been higher if not for some features of micro and small incubated entrepreneurs, among which stand out:

a. Entrepreneurs' profile: this factor directly influenced the results achieved by each company. It was found that entrepreneurs with bold profile (companies 3, 7, 8 and 9) obtained better results than entrepreneurs with moderate or conservative profile (companies 1, 2, 4 and 6). For company 5, in particular, the 
conservative profile of one partner hindered best achievements that could be done with the activities planned by the partner with bold profile;

b. Lack of experience of micro or small business: the lack of experience of some micro or small business in management techniques made impossible to obtain better results, as they will require a longer preparation. Some of them had simple management techniques and, therefore, needed a better conceptual basis in the early implementation (companies 1 and 6). After training preparation, their businesses have evolved and started to present results.

c. Performance indicators focusing only on financial aspects: with the exception of enterprises 7 and 8 that also analyzed non-financial indicators, all other companies recorded only indicators related to financial aspects. The most commonly used were invoicing, profit and debt, not being considered in any of these companies returns on investments. The adapted quality management system helped these companies to better understand the importance of having a more balanced portfolio of indicators.

d. Difficulty in getting the initial integration of all partners: a common feature to all companies with more than one partner was the difficulty in getting the initial integration of them to carry out the implementation activities. In the early implementation activities in companies $2,4,5,6$, and 9 were made by only one of the partners, and only after a few months the entire direction get integrated.

e. Lack of constancy of purpose: in the company 2 there was a lack of constancy of purpose, since it was not properly devoted to weekly activities and abandoned the implementation a few months later;

f. Allegation of lack of time to perform some implementation tasks: the companies 3, 4, 5 and 6 claimed lack of sufficient time to perform the weekly tasks related to the adapted quality management system implementation. When this data was compared with the number of overtime worked hours, it was found that only 5 companies made a lot of overtime, so the claim of the other companies was too controversial. After the third month of implementation, this situation was regularized and the participation in weekly activities was increased greatly.

g. Difficulty setting goals and long-term strategic plans: almost all companies had difficulty in establishing goals and performance indicators of long-term performance before the adapted quality management system implementation. After the second phase implementation, this difficulty dramatically reduced, and the companies have established strategic horizons greater than 3 years.

h. Behavior of micro or small business versus end of the incubation period: another interesting factor to be discussed was the behavior of micro or small business due to the remaining period of the end of the incubation period. For companies 1, 3, and 6, the closer the departure of the incubator, the greater the carelessness with maintaining the senses of quality. The organization provided by the $5 \mathrm{~S}$ was re-established after the allocation of the company at its own facilities.

i. Lack of vision of employees as contributors for the company's growth: before the adapted quality management system implementation all owners refused to pass some information about the goals and the company's performance to their employees, because they could not see them as collaborators. After implementation, only the company 3 continued not to disclose these indicators.

j. More bureaucratic documents than necessary for the company: this was a difficulty experienced mainly in the company 7 early in implementation because its owners have worked in multinational companies and developed internal documents based on large enterprise documents. Over time, this trend was eliminated.

k. High turnover of workforce: this was a critical factor evidenced in companies 3, 4, 6 and 9 and prevented a better efficiency of the adapted quality management system since new company employees needed to be constantly trained. Through training, we tried to show the micro and small businesses that in many situations it was more advantageous to keep an employee rather than let him leave for another company.

1. Little use of some quality records: all companies used to record customer complaints, control of nonconforming product, nonconformities, meetings, critical analysis of related products and critical analysis of the management system. However, with the exception of companies 4, 7 and 8 , there was a small use of records for design changes (when applicable), changes in documents of quality and calibration of instruments. In the implementation final phase, which there was a great balance of achieved improvements and opportunities for improvement, the situation was resolved and virtually all of the suggested records began to be used by the companies. 


\section{Conclusions and Discussion}

The system implementation of quality management as presented by ISO 9001 standard (ISO, 2008) enables gains to any company regardless its size or activity sector. However, for those companies that are still in their early years, a system like the one proposed by ISO may appear somewhat complex, in particular for the lack of experience of entrepreneurs and their peculiar characteristics which such companies are subject. Thus, an adapted quality management system enables better results as can be proven by some data presented in this article.

Through the adapted quality management system implementation in nine companies of the Center for Entrepreneurial Development Jundiaí, there were optimal results for all companies (except company 2 that did not complete the implementation) and it was considered how the main characteristics related to micro and small entrepreneurs influenced the benefits achieved by each one of them. As an example of the main difficulties experienced during the implementation and that were solved by adapted quality management system, it is highlighted the lack of vision of entrepreneurs that their employees could contribute to the growth of the company, the lack of long-term strategic vision, managing only financial indicators, among others.

Finally, the information reported here is an important source of data for quality programs implementation in incubated companies of any country. With this information, the authors of this article and other researchers interested in this area may improve their training and develop better tools to the reality of micro and small businesses. The detailed results obtained by the implementation of quality management system in every company can be obtained by contacting the authors of this article.

\section{References}

Al-Mubaraki, H. M; Busler, M. (2010). "Business incubators models of the USA and UK: A SWOT analysis", World Journal of Entrepreneurship, Management and Sustainable Development, Vol. 6 Iss 4 pp. 335 - 354. http://dx.doi.org/10.1108/20425961201000025

Eikebrokk, T.R. \& Olsen, D.H. (2007). An empirical investigation of competency factors affecting e-business success in European SMEs. Information \& Management, Vol. 44, pp. 364-383. http://dx.doi.org/10.1016/j.im.2007.02.004

Falconi, V.C. (Editor). (1992). Total Quality Control: Japanese way to quality. UFMG, Minas Gerais, Brazil.

GEM. (2013). "GEM 2013 Global Report", Global Entrepreneurship Monitor, Santiago, Chile. Available $<\mathrm{http}$ //www.gemconsortium.org/docs/3106/gem-2013-global-report>. (accessed 06 de January 2014) (in portuguese)

Hakserver, C. (1996). "Total Quality Management in the small business environment" Business Horizon, Vol. 39, pp. 33-34. http://dx.doi.org/10.1016/S0007-6813(96)90021-X

Ilkai, P. \& Aslan, A. (2012). "The effect of ISO 9001 quality management system on the performance of SMEs" Business Process Management Journal, Vol. 29, pp 753-778. http://dx.doi.org/10.1108/02656711211258517

ISO. (2008). Quality Management Requirements. International Organization for Standardization. Geneva.

Kaplan, R.S. \& Norton, D.P (Editors). (1997). The Balanced Scorecard: Translating Strategy into Action. Harvard Business Review Press, New York, USA.

Koc, T. (2011). "Innovation Antecedents: comparative research on large firms and SMEs" International Journal of Industrial Engineering, Vol. 18, pp 328-338.

Kumar, S. Mantha, S.S. Kumar, A. (2009). "Scrap Reduction by using Total Quality Management Tools" International Journal of Industrial Engineering, Vol. 16, pp 364-369.

Longenecker, J.G., Petty, J.W., Palich, L.E. \& Hoy, F. (Editors). (2013). Small Business Management: Launching \& Growing Entrepreneurial Ventures. Cengage Learning, New York, USA.

McADAM, R. (2000). "Quality Models in SMEs context". International Journal of Quality \& Reliability Management, Vol. 17, pp. 305-323. http://dx.doi.org/10.1108/02656710010306166

MCT. (2014). Ministry of Science and Technology. Handbook to Business Incubator. Avaible at: http://www.mct.gov.br/Temas/Desenv/Manual-Incubadoras.pdf (accessed 06 de January 2014) (in portuguese) 
Munsterman, B., Eckhardt, A. \& TIM, W. (2010). "The performance impact of business process standardization: an empirical evaluation of the recruitment process". Business Process Management Journal, Vol 16, pp. 29-56. http://dx.doi.org/10.1108/14637151011017930

Nwankwo, S. (2000). "Quality Assurance in small business: myths and realities". International Journal of Quality \& Reliability Management, Vol. 11, pp 82-99. http://dx.doi.org/10.1108/02656710010302269

PPQG. (2013). "São Paulo State Quality Management Award". Brazil. Available http://www.ipeg.org.br/premiopaulista/criterios.html> (accessed 12 de may 2013) (in portuguese)

Sebrae. (2009). "Datas of Brazilian Service to support micro and small enterprises". Available at http://www.sebrae.com.br/sites/PortalSebrae (accessed 15 November 2013) (in portuguese)

Sebrae. (2014). "Regulation of micro and small enterprises". Brazilian Service to Support Micro and Small Enterprises". Available at http://www.sebrae.com.br/sites/PortalSebrae (accessed 03 February 2014)

Sebrae-SP. (2013). "Generals". Brazilian Service to support micro and small enterprises: São Paulo State, Brazil Office. Available at http://www.sebraesp.com.br (accessed 20 December 2013) (in portuguese)

Souza-Poza, A., Altinkilinc, M. \& Searcy, C. (2008). "Implementing a Functional ISO 9001 Quality Management System in Small and Medium-Sized Enterprises" International Journal of Engineering, Vol 3, pp. 220-232.

Spencer, M.S. \& Lomba, A.P.S. (2001). "Total Quality Management Programmes at smaller manufacturers: benchmarking techniques and results" Total Quality Management, Vol 12, pp 689-695. http://dx.doi.org/10.1080/09544120120060156

Youssef, A. \& Aldowaisan, T. (2006). "An ISO 9001:2000-based framework for realizing quality in small businesses" Omega, 34: 231-235. http://dx.doi.org/10.1016/j.omega.2004.10.007

Williams, A.R.T., Brown, A. \& Dale, B.G. (2001). "The ISO 9000 series as a tool for organization change: is there a case?" Business Process Management Journal, Vol 7, pp. 323-331. http://dx.doi.org/10.1108/EUM0000000005731

Wonglimpiyarat; J. (2014). "Incubator policy to support entrepreneurial development, technology transfer and commercialization", World Journal of Entrepreneurship, Management and Sustainable Development, Vol. 10 Iss 4 pp. 334 - 351. http://dx.doi.org/10.1108/WJEMSD-03-2014-0008 